\title{
A Novel Family of [1,4]Thiazino[2,3,4-ij]quinolin-4-ium Derivatives: Regioselective Synthesis Based on Unsaturated Heteroatom and Heterocyclic Compounds and Antibacterial Activity
}

\author{
Vladimir A. Potapov*(D), Roman S. Ishigeev ${ }^{(D}$, Lyudmila A. Belovezhets and Svetlana V. Amosova ${ }^{D}$ \\ A. E. Favorsky Irkutsk Institute of Chemistry, Siberian Division of the Russian Academy of Sciences, 1 Favorsky \\ Str., 664033 Irkutsk, Russia; ishigeev@irioch.irk.ru (R.S.I.); belovezhets@irioch.irk.ru (L.A.B.); \\ amosova@irioch.irk.ru (S.V.A.) \\ * Correspondence: v.a.potapov@mail.ru
}

check for updates

Citation: Potapov, V.A.; Ishigeev, R.S.; Belovezhets, L.A.; Amosova, S.V. A Novel Family of [1,4]Thiazino[2,3,4-ij]quinolin-4-ium Derivatives: Regioselective Synthesis Based on Unsaturated Heteroatom and Heterocyclic Compounds and Antibacterial Activity. Molecules 2021, 26, 5579. https://doi.org/10.3390/ molecules26185579

Academic Editor: Jacek Nycz

Received: 1 August 2021

Accepted: 9 September 2021

Published: 14 September 2021

Publisher's Note: MDPI stays neutral with regard to jurisdictional claims in published maps and institutional affiliations.

Copyright: (c) 2021 by the authors. Licensee MDPI, Basel, Switzerland. This article is an open access article distributed under the terms and conditions of the Creative Commons Attribution (CC BY) license (https:// creativecommons.org/licenses/by/ $4.0 /)$.

\begin{abstract}
A novel family of [1,4]thiazino[2,3,4-ij]quinolin-4-ium derivatives was synthesized by annulation reactions of 8-quinolinesulfenyl chloride with unsaturated heteroatom and heterocyclic compounds. It was found that the reactions with 4-pentenoic and 5-hexenoic acids, allyl chloride and bromide, allyl cyanate and vinyl heterocyclic compounds ( $N$-vinyl pyrrolidin-2-one and 1 vinylimidazole) proceeded in a regioselective mode but with the opposite regiochemistry. The reactions with vinyl heterocyclic compounds included electrophilic addition of the sulfur atom of 8quinolinesulfenyl chloride to the $\beta$-carbon atom of the vinyl group. In the case of other substrates, the annulation proceeded with the attachment of the sulfur atom to the $\alpha$-carbon atom of the vinyl group. The antibacterial activity of novel water-soluble compounds against Enterococcus durans, Bacillus subtilis and Escherichia coli was evaluated. Compounds with high antibacterial activity were found.
\end{abstract}

Keywords: annulation reactions; [1,4]thiazino[2,3,4-ij]quinolin-4-ium derivatives; 8-quinolinesulfenyl chloride; heterocycles; 4-pentenoic acid; 5-hexenoic acid; allyl halides

\section{Introduction}

Quinoline derivatives are used in the development of new drugs and exhibit a wide spectrum of biological activity [1-5]. Many medications contain the quinoline ring including antibacterial, antivirus and antimalarial (chloroquine, hydroxychloroquine, amodiaquine, primaquine) drugs [1-5]. The fluoroquinolone antibiotics (ciprofloxacin, levofloxacin, moxifloxacin, et al.) are one of most important classes of broad-spectrum bacteriocidals, which are very effective against both Gram-negative and Gram-positive bacteria [1]. A number of fluoroquinolone antibiotics (rufloxacin, levofloxacin, nadifloxacin) have a tricyclic core structure (Figure 1).

A combination of the quinoline scaffold with condensed sulfur-containing heterocycles has proven a fruitful approach in the development of new drugs [6,7]. Valuable examples of such combinations include penicillin and cephalosporin antibiotics, as well as the fluoroquinolone antibiotics prulifloxacin and rufloxacin (Figure 1). Levofloxacin and nadifloxacin represent antibiotics containing the quinoline scaffold condensed with sixmembered cyclic structures (Figure 1).

A quinoline core structure fused with a thiazine heterocycle is a valuable scaffold for the development of derivatives with possible biological activity [8-11]. The $2 \mathrm{H}, 3 \mathrm{H}-$ [1,4]thiazino[2,3,4-ij]quinolin-4-ium derivatives show various biological activities [12-20] including anticancer [18], antibacterial [19] and anti-tuberculosis [20] properties. The commonly used antibiotic rufloxacin can be also considered a $2 H, 3 H-[1,4]$ thiazino[2,3,4ij]quinolin-4-ium derivative (Figure 1). 
<smiles>CN1CCN(c2c(F)cc3c(=O)c(C(=O)O)cn4c3c2SCC4)CC1</smiles>

Rufloxacin<smiles>C[C@@H]1COc2c(N3CCN(C)CC3)c(F)cc3c(=O)c(C(=O)O)cn1c23</smiles>

Levofloxacin<smiles>O=C(O)c1cn2c3c(c(N4CCC(O)CC4)c(F)cc3c1=O)CCC2[N+](=O)[O-]</smiles>

Nadifloxacin<smiles>CC1CSc2c(Br)c(F)cc3cc(C(=O)O)c(=O)n1c23</smiles>

10-Bromo-9-fluoro-3-methyl-5-oxo2,3-dihydro-5H-[1,4]thiazino[2,3,4-ij]quinoline-6-carboxylic acid (antibacterial)<smiles>CN1CCN(c2c(F)cc3c(=O)c4c5c=3n(c2SCC5)C=C4C=NNC(=O)c2ccncc2)CC1</smiles>

$N^{\prime}$-[9-Fluoro-10-(4-methylpiperazino)-5-oxo-2,3dihydro-5H-[1,4]thiazino[2,3,4-ij]quinolin-6-yl]methylideneisonicotinohydrazide (anti-tuberculosis)<smiles>CC1CSc2c(N3CCC(C4(N)CC4)C3)c(F)cc3cc(C(=O)O)c(=O)n1c23</smiles>

10-[3-(1-Aminocyclopropyl)-1-pyrrolidinyl]9-fluoro-3-methyl-5-oxo-2,3-dihydro-5 $\mathrm{H}$-[1,4]thiazino[2,3,4-ij]quinoline-6-carboxylic acid (antibacterial)

Figure 1. Known biologically active tricyclic quinoline compounds structurally related to the $2 H, 3 H-$ [1,4]thiazino[2,3,4-ij]quinolin-4-ium scaffold (fluoroquinolone antibiotics [1-5], compounds with antibacterial [19] and antituberculosis [20] activity).

The development of a method for the efficient regioselective synthesis of novel heterocyclic and condensed organochalcogen compounds by cyclization and annulation reactions of chalcogen reagents is the focus of our research [21-34]. Recently we described the annulation reactions of 8-pyridinesulfenyl halides with functionalized alkenes and cycloalkenes affording a series of $2 \mathrm{H}, 3 \mathrm{H}$-[1,4]thiazino[2,3,4-ij]quinolin-4-ium derivatives in high yields $[33,34]$. For example, the annulation reactions with divinyl and vinyl phenyl sulfides proceeded with the attachment of the sulfur atom of 8-pyridinesulfenyl halides at the $\beta$-position of the vinylsulfanyl group, while the addition of the sulfur atom occurred at the $\alpha$-carbon atom of the vinylsilyl moiety in the case of tetravinyl silane with the formation of 2-(trivinylsilyl)-2H,3H-[1,4]thiazino[2,3,4-ij]quinolin-4-ium chloride (1) (Scheme 1).<smiles>[R]SC1CSc2cccc3ccc[n+]1c23</smiles><smiles>[R]SC=C</smiles>

94-97\%

$$
\mathrm{R}=\mathrm{CH}_{2}=\mathrm{CH}, \mathrm{C}_{6} \mathrm{H}_{5}
$$<smiles>Cl[Si]c1cccc2cccnc12</smiles><smiles>C=C[Si](C=C)(C=C)C=C</smiles>

$98 \%$<smiles></smiles>

1

Scheme 1. The annulation reactions of 8-quinolinesulfenyl chloride with vinyl sulfides and tetravinyl silane.

Despite some progress in the development of synthetic methods for the preparation of $2 \mathrm{H}, 3 \mathrm{H}$-[1,4]thiazino[2,3,4-ij]quinolin-4-ium derivatives [33-41], the annulation reactions of 8-quinolinesulfenyl halides with a number of vinylic heteroatom compounds (4-pentenoic acid, 5-hexenoic acid, allyl chloride and bromide, allyl cyanate, $N$-vinyl pyrrolidin-2-one, 1- 
vinylimidazole, ethyl and butyl vinyl ethers) have not been described in the literature. The synthesis of novel families of compounds with potential biological activity and evaluation of their antimicrobial properties represent urgent tasks.

The goal of this research is the development of a method for the regioselective synthesis of a novel family of $[1,4]$ thiazino[2,3,4-ij]quinolin-4-ium derivatives based on the annulation reactions of 8-quinolinesulfenyl chloride with unsaturated heteroatom and heterocyclic compounds (4-pentenoic acid, 5-hexenoic acid, allyl chloride and bromide, allyl cyanate, $\mathrm{N}$-vinyl pyrrolidin-2-one, 1-vinylimidazole, 2,3-dihydrofuran, ethyl and butyl vinyl ethers) and the evaluation of their antibacterial activity.

\section{Results and Discussion}

The action of sulfuryl chloride on di(8-quinolinyl) disulfide (2) in methylene chloride or chloroform led to the generation of 8-quinolinesulfenyl chloride (3), which was used in situ without isolation in further reactions with unsaturated heteroatom compounds (Scheme 2).<smiles>c1cnc2c(SSc3cccc4cccnc34)cccc2c1</smiles>

2

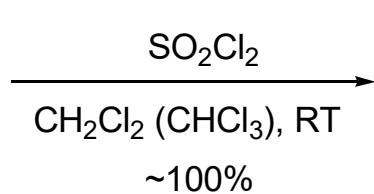

$\sim 100 \%$<smiles>[Si]c1cccc2cccnc12</smiles>

3

Scheme 2. The generation of 8-quinolinesulfenyl chloride 3 from di(8-quinolinyl) disulfide 2 by the action of sulfuryl chloride.

Condensed water-soluble organic salts containing carboxyl function are very promising with respect to possible biological activity. We obtained [1,4]thiazino[2,3,4-ij]quinolin4-ium derivatives based on the annulation reactions of 8-quinolinesulfenyl chloride 3 with terminal alkenes bearing the carboxylic acid function: 4-pentenoic and 5-hexenoic acids. When the annulation of 8-quinolinesulfenyl chloride with 4-pentenoic acid and 5-hexenoic acids was carried out in methylene chloride at room temperature, the reaction was found to be very sluggish. However, refluxing the reaction mixture in chloroform for $8 \mathrm{~h}$ made it possible to obtain 2-(3-carboxyethyl)- and 2-(3-carboxypropyl)-2H,3H-[1,4]thiazino[2,3,4ij]quinolin-4-ium chlorides 4 and 5 with $70-72 \%$ yields (Scheme 3 ). Refluxing the reaction mixture in methylene chloride for $8 \mathrm{~h}$ gave products 4 and 5 with only $49-52 \%$ yields.<smiles></smiles>

4

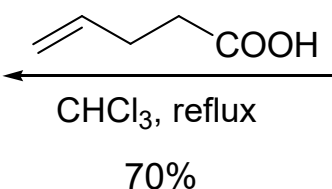

$70 \%$<smiles>Cl[Si]c1cccc2cccnc12</smiles>

3

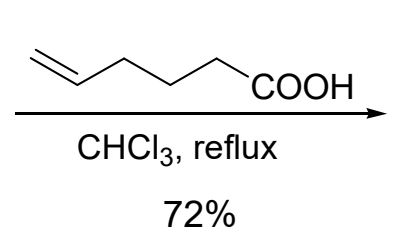

$72 \%$<smiles></smiles>

5

Scheme 3. Synthesis of 2-(3-carboxyethyl)- and 2-(3-carboxypropyl)-2H,3H-[1,4]thiazino[2,3,4-ij]quinolin-4-ium chlorides 4 and 5 from sulfenyl chloride 3, 4-pentenoic and 5-hexenoic acids.

Compounds 4 and 5 are light yellow water-soluble powders with a melting point above $160{ }^{\circ} \mathrm{C}$.

Allylchloride and allylbromide were involved in the annulation reactions with 8quinolinesulfenyl chloride 3 . By carrying out the reaction of sulfenyl chloride 3 with allylchloride and allylbromide under the same conditions as the synthesis of compounds 4 and 5 (refluxing the reaction mixture in chloroform for $8 \mathrm{~h}$ ), 2-chloromethyl- and 2- 
(bromomethyl)-2H,3H-[1,4]thiazino[2,3,4-ij]quinolin-4-ium chlorides 6 and 7 were synthesized with $98 \%$ and $90 \%$ yields, respectively (Scheme 4 ).<smiles></smiles>

6

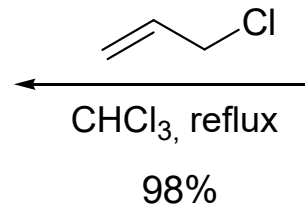<smiles>[Si]c1cccc2cccnc12</smiles>

3

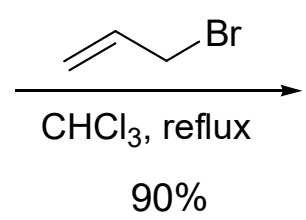

$90 \%$<smiles></smiles>

7

Scheme 4. Synthesis of 2-(chloromethyl)- and 2-(bromomethyl)-2H,3H-[1,4]thiazino[2,3,4-ij]quinolin-4-ium chlorides 6 and 7 from allylchloride, allylbromide and sulfenyl chloride 3.

The presence of carboxyl function and halogen atoms in structure of compounds 4-7 opens up opportunities for their functionalization by esterification, the nucleophilic substitution of halogen and other reactions.

The reaction of 8-quinolinesulfenyl chloride 3 with allyl cyanate was very sluggish at room temperature in methylene chloride. However, carrying out the reaction of sulfenyl chloride 3 with allyl cyanate for $8 \mathrm{~h}$ in refluxing chloroform made it possible to obtain 2-cyanomethyl-2H,3H-[1,4]thiazino[2,3,4-ij]quinolin-4-ium chlorides 8 with a $96 \%$ yield (Scheme 5). Refluxing the reaction mixture in methylene chloride for $8 \mathrm{~h}$ led to product 8 with only a $67 \%$ yield.<smiles>[Si]c1cccc2cccnc12</smiles>

3 3

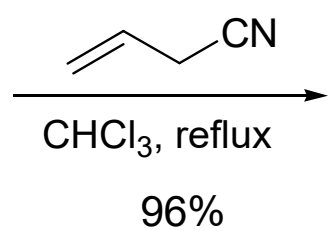

$96 \%$<smiles>N#CCC1C[n+]2cccc3cccc(c32)S1</smiles>

8

Scheme 5. Synthesis of 2-cyanomethyl-2H,3H-[1,4]thiazino[2,3,4-ij]quinolin-4-ium chloride 8 from sulfenyl chloride 3 and allylcyanate.

Compounds 6-8 are light yellow water-soluble powders with melting points of 138$140{ }^{\circ} \mathrm{C}, 162-164^{\circ} \mathrm{C}$ and $183-185^{\circ} \mathrm{C}$, respectively.

The involvement of substrates bearing potentially pharmacophoric heterocycles in annulation reactions is important in terms of the possible manifestation of biological activity. 1-Vinylimidazole and $N$-vinyl pyrrolidin-2-one, which contain a vinyl group bonded to a nitrogen atom, were involved in the annulation reactions with 8-quinolinesulfenyl chloride 3. The latter compound is an example of a heterocycle bearing a vinyl amide moiety in its structure.

The annulation reaction of 8-quinolinesulfenyl chloride 3 with 1-vinylimidazole was carried out at room temperature in methylene chloride, affording 3-(1H-imidazol-1-yl)$2 \mathrm{H}, 3 \mathrm{H}$-[1,4] thiazino[2,3,4-ij]quinolin-4-ium chloride (9) with a 75\% yield (Scheme 6).

Under the same conditions, the annulation reaction of 8-quinolinesulfenyl chloride 3 with $N$-vinyl pyrrolidin-2-one gave the annulation products with a $59 \%$ yield along with some by-products. It was found that this reaction proceeded more efficiently and selectively in the presence of potassium perchlorate.

3-(2-Oxopyrrolidin-1-yl)-2H,3H-[1,4]thiazino[2,3,4-ij]quinolin-4-ium perchlorate (10) was obtained with a $70 \%$ yield by the reaction of 8 -quinolinesulfenyl chloride 3 with $N$-vinyl 
pyrrolidin-2-one in the presence of an equimolar amount of potassium perchlorate (Scheme 6).<smiles></smiles>

9<smiles>C=Cn1ccnc1C</smiles>

$75 \%$<smiles>[Si]c1cccc2cccnc12</smiles>

3

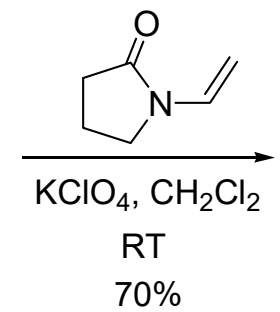

$70 \%$<smiles></smiles>

10

Scheme 6. Synthesis of 3-(1H-imidazol-1-yl)-2H,3H-[1,4]thiazino[2,3,4-ij]quinolin-4-ium chloride 9 and 3-(2-oxopyrrolidin1-yl)-2H,3H-[1,4]thiazino[2,3,4-ij]quinolin-4-ium perchlorate (10) from sulfenyl chloride 3 and 1-vinylimidazole and $N$-vinyl pyrrolidin-2-one.

Attempts were made to increase the yields by refluxing the reaction mixture in methylene chloride or chloroform. This made it possible to obtain products $\mathbf{9}$ and $\mathbf{1 0}$ with 90-94\% yields; however, the selectivity of the reactions decreased, and compounds 9 and 10 were contaminated with by-products $(6-10 \%)$, from which it was difficult to separate the target compounds.

The reactions with 4-pentenoic and 5-hexenoic acids, allylchloride, allylbromide and allyl cyanate included the electrophilic addition of the sulfur atom from sulfenyl chloride 3 to the $\alpha$-carbon atom of the vinyl group ("anti-Markovnikov direction"), while the annulation reactions with $N$-vinyl pyrrolidin-2-one and 1-vinylimidazole proceeded with the attachment of the sulfur atom to the $\beta$-carbon atom of the vinyl group ("Markovnikov direction"). We presume that the reactions of sulfenyl chloride 3 with $N$-vinyl pyrrolidin2-one and 1-vinylimidazole proceed via linear intermediates B (Scheme 7) which are stabilized by the nitrogen atom (the nitrogen atom's ability to stabilize adjacent carbocation is well known [42]).

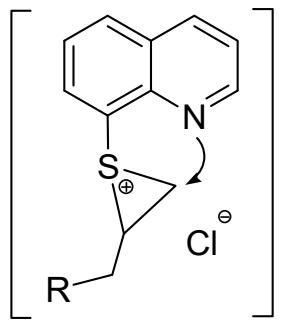

A<smiles>[R]CC1C[n+]2cccc3cccc(c32)S1</smiles><smiles>Cl[Si]c1cccc2cccnc12</smiles>

3

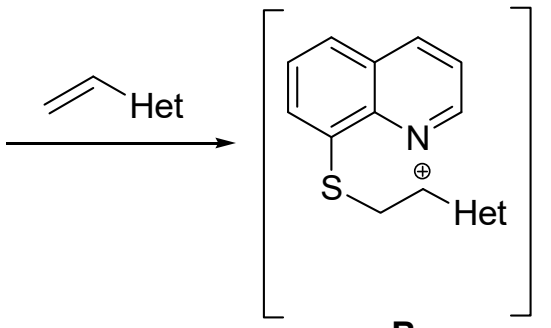

B<smiles>C=C[C+]=Cn1ccnc1</smiles>

$\mathrm{R}=\mathrm{CH}_{2} \mathrm{COOH}(4), \mathrm{CH}_{2} \mathrm{CH}_{2} \mathrm{COOH}(5), \mathrm{Cl}(6), \mathrm{Br}(7), \mathrm{CN}(8)$

Scheme 7. Directions of the reactions of sulfenyl chloride 3 with unsaturated heteroatom and heterocyclic compounds.

It is known that the electrophilic addition of sulfenyl chlorides [43-52] to linear 1alkene leads predominantly to anti-Markovnikov products [43-46] and thiiranium cations are regarded as intermediates in these reactions [43-48]. In the cases of 4-pentenoic and 
5-hexenoic acids, allylchloride, allylbromide and allyl cyanate, there are no heteroatoms (adjacent to the double bond) which could stabilize the intermediates, and the reactions take place via thiiranium intermediate $\mathbf{A}$. Taking into account the steric factor, the nucleophilic attack of the nitrogen atom of the quinoline ring occurs at the unsubstituted carbon atom of thiiranium intermediate A and this course determines the "anti-Markovnikov direction" of the reactions (Scheme 7).

Vinyl ethers are promising substrates for annulation reactions due to the high reactivity of these compounds in electrophilic additions. The reactions of sulfenyl chloride 3 with ethyl vinyl and butyl vinyl ethers proceeded smoothly at room temperature in methylene chloride, producing 3-ethoxy- and 3-butoxy-2H,3H-[1,4]thiazino[2,3,4-ij]quinolin-4-ium chlorides 11 and $\mathbf{1 2}$ in quantitative yields (Scheme 8).<smiles></smiles>

11

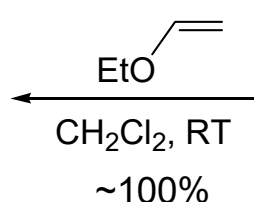

$\sim 100 \%$<smiles>Cl[SiH3]c1cccc2cccnc12</smiles>

3

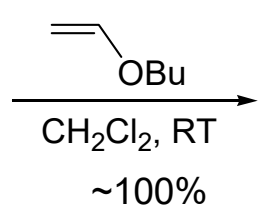

$\sim 100 \%$<smiles></smiles>

12

Scheme 8. Synthesis of 3-ethoxy- and 3-butoxy-2H,3H-[1,4]thiazino[2,3,4-ij]quinolin-4-ium chlorides 11 and 12 from sulfenyl chloride 3 and ethyl vinyl and butyl vinyl ethers.

Like the synthesis of products 9 and 10, the reactions of sulfenyl chloride 3 with ethyl vinyl and butyl vinyl ethers are believed to occur via linear intermediates (similar to intermediate $\mathbf{B}$, Scheme 7 ), which are stabilized by the oxygen atom (the oxygen atom exhibits a strong ability to stabilize adjacent carbocation [53]).

Finally, based on the reaction of sulfenyl chloride 3 with cyclic vinyl ether, 2,3dihydrofuran, we synthesized the condensed four-membered heterocycle 13, which is of interest for evaluation of antibacterial activity and comparison with the antibacterial properties of products $\mathbf{1 1}$ and 12, obtained from ethyl vinyl and butyl vinyl ethers. The reactions of sulfenyl chloride 3 with 2,3-dihydrofuran was carried out in the presence of an equimolar amount of $\mathrm{KClO}_{4}$ at room temperature in methylene chloride, leading to perchlorate 13 with a $72 \%$ yield (Scheme 9 ).<smiles>[Si]c1cccc2cccnc12</smiles>

3

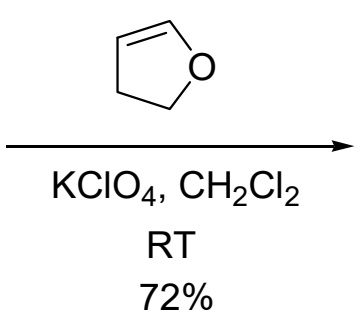

$72 \%$<smiles>O=[N+]1c2cccc3cccc(c23)SC2CCOC21</smiles>

13

Scheme 9. Synthesis of $7 \mathrm{a} H, 8 H, 9 H, 10 \mathrm{a} H$-furo[2 $\left.2^{\prime}, 3^{\prime}: 5,6\right][1,4]$ thiazino[2,3,4-ij]quinolin-11-ium perchlorate (13) from sulfenyl chloride 3, 2,3-dihydrofuran and potassium perchlorate.

Similarly to the reactions with ethyl vinyl and butyl vinyl ethers (Scheme 8), synthesis of compound 13 was regioselective and the sulfur atom of sulfenyl chloride 3 bonded to the $\beta$-carbon atom of the vinyloxy group.

The antibacterial activity of the synthesized compounds was evaluated. The minimal inhibitory concentration (MIC) was determined using the broth standard microdilution method [54].

Compounds 1, 4-13 were tested in vitro for antibacterial activity against bacterial strains of gram-positive Enterococcus durans B-603, Bacillus subtilis B-406 and gram-negative Escherichia coli B-1238 (the bacterial strains were taken from the All-Russian Collection of Microorganisms) and the obtained results were compared to the activity of standard 
aminoglycoside antibiotic gentamicin (the minimal inhibitory concentrations are 25, 50 and $100 \mu \mathrm{g} / \mathrm{mL}$ against $E$. durans, B. subtilis and E. coli, respectively). The obtained results are presented in the Table 1.

The activities of compounds 4 and 5 , which differ only in one $\mathrm{CH}_{2}$ group, are significantly different. Compound 5, with its longer carbon chain, exhibited considerably higher activity against gram-positive E. durans and B. subtilis and is superior to antibiotic gentamicin in this respect (Table 1).

Table 1. Evaluation of the antibacterial activity of compounds 1, 4-13.

Minimum Inhibitory Concentration $(\mu \mathrm{g} / \mathrm{mL})$
$\begin{gathered}\text { Bacillus } \\ \text { subtilis }\end{gathered}$
$\begin{gathered}\text { Enterococcus } \\ \text { colic }\end{gathered}$


Table 1. Cont.

\begin{tabular}{|c|c|c|c|c|}
\hline \multirow[b]{2}{*}{ No } & \multirow[b]{2}{*}{ Compound } & \multicolumn{3}{|c|}{ Minimum Inhibitory Concentration $(\mu \mathrm{g} / \mathrm{mL})$} \\
\hline & & $\begin{array}{c}\text { Enterococcus } \\
\text { durans }\end{array}$ & $\begin{array}{l}\text { Bacillus } \\
\text { subtilis }\end{array}$ & $\begin{array}{l}\text { Escherichia } \\
\text { coli }\end{array}$ \\
\hline \multicolumn{5}{|l|}{12} \\
\hline & & 31.5 & 1000 & 125 \\
\hline \multicolumn{5}{|l|}{13} \\
\hline & $\mathrm{ClO}_{4}$ & 3.1 & 12.5 & 250 \\
\hline \multicolumn{5}{|c|}{ Gentamicin * } \\
\hline & & 25 & 50 & 100 \\
\hline
\end{tabular}

* Antibiotic gentamicin was used as a control compound.

Compounds 6 and 7 differ only in the halogen atom. Bromo-containing compound 7 was 40 times more effective than its chlorine analogue 6 against $E$. durans. However, product 6 was the most effective among the obtained compounds against gram-negative bacteria E. coli. Silicon-containing product $\mathbf{1}$ and compound $\mathbf{8}$ showed low activity. Compound $\mathbf{9}$ exhibited average activity against all tested bacteria (Table 1).

The comparison of compounds 11-13 revealed higher activity in products $\mathbf{1 1}$ and $\mathbf{1 3}$ (obtained from ethyl vinyl ether and 2,3-dihydrofuran), at levels which were superior to the activity of gentamicin against gram-positive bacteria.

The highest activity was shown by product 10 (obtained from $N$-vinyl pyrrolidin-2one), which significantly exceeded the activity of gentamicin and all obtained compounds against gram-positive bacteria and was more than a hundred times superior to this antibiotic against B. subtilis (Table 1 ).

The structural assignments of synthesized compounds were made using ${ }^{1} \mathrm{H}$ and ${ }^{13} \mathrm{C}$ NMR spectroscopy, including two-dimensional experiments (Supplementary Materials containing examples of NMR spectra are available online), and confirmed by elemental analysis.

The products with the opposite regiochemistry show the characteristic signals of carbon atoms bonded with a charged nitrogen $\left(\mathrm{N}^{+}\right)$atom and a sulfur atom. The number of protons (one or two) bonded to the carbon atoms adjacent to the charged nitrogen atom and to the sulfur atom is important (the number of protons is determined by NMR experiments). For example, the $\mathrm{CHS}$ moiety and the $\mathrm{CH}_{2} \mathrm{~N}^{+}$methylene group manifested themselves in the regions of $32-43 \mathrm{ppm}$ and 58-64 ppm, respectively, in the ${ }^{13} \mathrm{C}-\mathrm{NMR}$ spectra of compounds 4-8 (the products derived from anti-Markovnikov addition of the sulfur electrophile to the double bond). Signals of the one-proton-containing $\mathrm{OCHN}^{+}$ moiety were observed in the downfield region of $91-92 \mathrm{ppm}$ in the ${ }^{13} \mathrm{C}-\mathrm{NMR}$ spectra of compounds 11-13 (the products derived from Markovnikov addition of the sulfur electrophile to the double bond).

\section{Experimental Section}

\subsection{General Information}

The ${ }^{1} \mathrm{H}(400.1 \mathrm{MHz})$ and ${ }^{13} \mathrm{C}(100.6 \mathrm{MHz})$ NMR spectra were recorded on a Bruker DPX-400 spectrometer (Bruker BioSpin GmbH, Rheinstetten, Germany) in 2-5\% solution in $\mathrm{D}_{2} \mathrm{O}$, DMSO- $d_{6}$, methanol- $d_{4}$ or acetone- $d_{6} .{ }^{1} \mathrm{H}$ and ${ }^{13} \mathrm{C}$ chemical shifts $(\delta)$ were reported in parts per million (ppm), relative to tetramethylsilane (external) or to the residual solvent 
peaks of $\mathrm{D}_{2} \mathrm{O}(\delta=4.79)$, acetone- $d_{6}(\delta=2.05$ and $29.84 \mathrm{ppm})$, methanol- $d_{4}(\delta=3.31$ and $49.0 \mathrm{ppm})$ and DMSO- $d_{6}\left(\delta=2.50\right.$ and $39.52 \mathrm{ppm}$ for ${ }^{1} \mathrm{H}$ and ${ }^{13} \mathrm{C}$ NMR, respectively). The term "quino" in spectral data indicates belonging to the quinoline ring. The elemental analysis was performed on a Thermo Scientific FLASH 2000 Organic Elemental Analyzer (Thermo Fisher Scientific Inc., Milan, Italy). Melting points were determined on a Kofler Hot-Stage Microscope PolyTherm A apparatus (Wagner \& Munz GmbH, München, Germany). Absolute solvents were used in the reactions.

\subsection{Synthesis of Compounds $\mathbf{4 - 8}$}

2-(3-Carboxyethyl)-2H,3H-[1,4]thiazino[2,3,4-ij]quinolin-4-ium chloride (4). A solution of sulfuryl chloride $(0.076 \mathrm{~g}, 0.56 \mathrm{mmol})$ in chloroform $(10 \mathrm{~mL})$ was added dropwise to a solution of di(8-quinolinyl) disulfide $(0.180 \mathrm{~g}, 0.56 \mathrm{mmol})$ in chloroform $(10 \mathrm{~mL})$, and the mixture was stirred for $10 \mathrm{~min}$ at room temperature. A solution of pentenoic acid $(0.112 \mathrm{~g}$, $1.12 \mathrm{mmol})$ in chloroform $(10 \mathrm{~mL})$ was added dropwise, and the reaction mixture stirred for $1 \mathrm{~h}$ at room temperature and $8 \mathrm{~h}$ at reflux temperature. After cooling in the refrigerator, the formed precipitate was filtered off and dried in a vacuum, producing the product $(0.232 \mathrm{~g}$, $70 \%$ yield) as a yellow powder, $\mathrm{mp} 170-172{ }^{\circ} \mathrm{C}$.

${ }^{1} \mathrm{H}-\mathrm{NMR}\left(400 \mathrm{MHz}, \mathrm{D}_{2} \mathrm{O}\right): \delta 1.80-1.90\left(\mathrm{~m}, 1 \mathrm{H}, \mathrm{CH}_{2}\right), 2.13-2.22\left(\mathrm{~m}, 1 \mathrm{H}, \mathrm{CH}_{2}\right), 2.65(\mathrm{t}$, $\left.J=7.2 \mathrm{~Hz}, 2 \mathrm{H}, \mathrm{CH}_{2}\right), 3.85-3.86(\mathrm{~m}, 1 \mathrm{H}, \mathrm{SCH}), 5.07\left(\mathrm{dd}, J=14.2,6.8 \mathrm{~Hz}, 1 \mathrm{H}, \mathrm{NCH}_{2}\right), 5.31(\mathrm{~d}$, $\left.J=14.3 \mathrm{~Hz}, 1 \mathrm{H}, \mathrm{NCH}_{2}\right), 7.74-7.77\left(\mathrm{~m}, 1 \mathrm{H}, \mathrm{C}_{\text {quino }}\right), 7.93-7.94\left(\mathrm{~m}, 1 \mathrm{H}, \mathrm{C}_{\text {quino }}\right), 8.00-8.04(\mathrm{~m}$, $\left.2 \mathrm{H}, \mathrm{C}_{\text {quino }}\right), 9.06-9.12\left(\mathrm{~m}, 2 \mathrm{H}, \mathrm{C}_{\text {quino }}\right)$.

${ }^{13} \mathrm{C}-\mathrm{NMR}\left(101 \mathrm{MHz}, \mathrm{D}_{2} \mathrm{O}\right): \delta 27.21\left(\mathrm{CH}_{2}\right), 31.81\left(\mathrm{CH}_{2}\right), 36.86(\mathrm{SCH}), 63.72\left(\mathrm{NCH}_{2}\right)$, 122.83 ( $\left.\mathrm{C}_{\text {quino }}\right), 126.27\left(\mathrm{C}_{\text {quino }}\right), 128.26$ ( $\left.\mathrm{C}_{\text {quino }}\right), 130.55\left(\mathrm{C}_{\text {quino }}\right), 131.91$ ( $\left.\mathrm{C}_{\text {quino }}\right), 134.43$ ( $\left.\mathrm{C}_{\text {quino }}\right), 134.50\left(\mathrm{C}_{\text {quino }}\right), 150.26\left(\mathrm{C}_{\text {quino }}\right), 150.40\left(\mathrm{C}_{\text {quino }}\right), 177.83(\mathrm{COOH})$.

Anal. Calcd for $\mathrm{C}_{14} \mathrm{H}_{14} \mathrm{ClNO}_{2} \mathrm{~S}$ : C 56.85, $\mathrm{H} 4.77, \mathrm{~N} 4.74, \mathrm{Cl} 11.99, \mathrm{~S} 10.84$. Found: C 56.97, H 4.91, N 4.96, Cl 12.35, S 11.21.

2-(3-Carboxypropyl)-2H,3H-[1,4]thiazino[2,3,4-ij]quinolin-4-ium chloride (5). A solution of sulfuryl chloride $(0.087 \mathrm{~g}, 0.64 \mathrm{mmol})$ in chloroform $(10 \mathrm{~mL})$ was added dropwise to a solution of di(8-quinolinyl) disulfide $(0.206 \mathrm{~g}, 0.64 \mathrm{mmol})$ in chloroform $(10 \mathrm{~mL})$, and the mixture was stirred for $10 \mathrm{~min}$ at room temperature. A solution of hexenoic acid $(0.147 \mathrm{~g}$, $1.28 \mathrm{mmol})$ in chloroform $(10 \mathrm{~mL})$ was added dropwise, and the reaction mixture stirred for $1 \mathrm{~h}$ at room temperature and $8 \mathrm{~h}$ at reflux temperature. After cooling in the refrigerator, the formed precipitate was filtered off and dried in a vacuum, producing the product $(0.286 \mathrm{~g}$, $72 \%$ yield) as a yellow powder, $\mathrm{mp} 161-162{ }^{\circ} \mathrm{C}$.

${ }^{1} \mathrm{H}-\mathrm{NMR}\left(400 \mathrm{MHz}, \mathrm{D}_{2} \mathrm{O}\right): \delta 1.68-1.86\left(\mathrm{~m}, 4 \mathrm{H}, \mathrm{CH}_{2}\right), 2.36\left(\mathrm{t}, \mathrm{J}=6.7 \mathrm{~Hz}, 2 \mathrm{H}, \mathrm{CH}_{2}\right)$, 3.70-3.77 (m, 1H, SCH), 4.97 (dd, $\left.J=14.2,7.8 \mathrm{~Hz}, 1 \mathrm{H}, \mathrm{NCH}_{2}\right), 5.26(\mathrm{~d}, J=14.2 \mathrm{~Hz}, 1 \mathrm{H}$, $\left.\mathrm{NCH}_{2}\right), 7.69-7.73\left(\mathrm{~m}, 1 \mathrm{H}, \mathrm{C}_{\text {quino }}\right), 7.88-7.90\left(\mathrm{~m}, 1 \mathrm{H}, \mathrm{C}_{\text {quino }}\right), 7.95-7.99\left(\mathrm{~m}, 2 \mathrm{H}, \mathrm{C}_{\text {quino }}\right)$, 9.02-9.09 (m, 2H, $\left.\mathrm{C}_{\text {quino }}\right)$.

${ }^{13} \mathrm{C}-\mathrm{NMR}\left(101 \mathrm{MHz}, \mathrm{D}_{2} \mathrm{O}\right): \delta 21.41\left(\mathrm{CH}_{2}\right), 30.36\left(\mathrm{CH}_{2}\right), 33.06\left(\mathrm{CH}_{2}\right), 36.27(\mathrm{SCH}), 62.91$ $\left(\mathrm{NCH}_{2}\right), 121.78\left(\mathrm{C}_{\text {quino }}\right), 125.90\left(\mathrm{C}_{\text {quino }}\right), 127.18\left(\mathrm{C}_{\text {quino }}\right), 129.60\left(\mathrm{C}_{\text {quino }}\right), 131.06\left(\mathrm{C}_{\text {quino }}\right)$, $133.43\left(\mathrm{C}_{\text {quino }}\right), 133.67\left(\mathrm{C}_{\text {quino }}\right), 149.16\left(\mathrm{C}_{\text {quino }}\right), 149.25\left(\mathrm{C}_{\text {quino }}\right), 178.03(\mathrm{COOH})$.

Anal. Calcd for $\mathrm{C}_{15} \mathrm{H}_{16} \mathrm{ClNO}_{2} \mathrm{~S}$ : C 58.15, $\mathrm{H}$ 5.21, N 4.52, $\mathrm{Cl} 11.44, \mathrm{~S} 10.35$. Found: C 58.73, H 5.61, N 4.69, Cl 11.89, S 10.91.

2-(Chloromethyl)-2H,3H-[1,4]thiazino[2,3,4-ij]quinolin-4-ium chloride (6). A solution of sulfuryl chloride $(0.065 \mathrm{~g}, 0.48 \mathrm{mmol})$ in chloroform $(10 \mathrm{~mL})$ was added dropwise to a solution of di(8-quinolinyl) disulfide $(0.154 \mathrm{~g}, 0.48 \mathrm{mmol})$ in chloroform $(10 \mathrm{~mL})$, and the mixture was stirred for $10 \mathrm{~min}$ at room temperature. A solution of allyl chloride $(0.073 \mathrm{~g}$, $0.96 \mathrm{mmol})$ in chloroform $(10 \mathrm{~mL})$ was added dropwise, and the reaction mixture stirred for $1 \mathrm{~h}$ at room temperature and $8 \mathrm{~h}$ at reflux temperature. The mixture was filtered and the solvent was removed by rotary evaporator. The residue was dried in a vacuum, producing the product $(0.260 \mathrm{~g}, 98 \%$ yield $)$ as a yellow powder, $\mathrm{mp} 138-140{ }^{\circ} \mathrm{C}$. 
${ }^{1} \mathrm{H}-\mathrm{NMR}\left(400 \mathrm{MHz}, \mathrm{D}_{2} \mathrm{O}\right): \delta 3.66-3.71\left(\mathrm{~m}, 1 \mathrm{H}, \mathrm{CH}_{2}\right), 4.03(\mathrm{dd}, J=11.7,5.6 \mathrm{~Hz}, 1 \mathrm{H}$, $\left.\mathrm{CH}_{2}\right), 4.20(\mathrm{~s}, 1 \mathrm{H}, \mathrm{SCH}), 5.34\left(\mathrm{~d}, J=14.3 \mathrm{~Hz}, 1 \mathrm{H}, \mathrm{NCH}_{2}\right), 5.48(\mathrm{dd}, J=14.3,4.7 \mathrm{~Hz}, 1 \mathrm{H}$, $\left.\mathrm{NCH}_{2}\right), 7.84-7.88\left(\mathrm{~m}, 1 \mathrm{H}, \mathrm{C}_{\text {quino }}\right), 8.03-8.12\left(\mathrm{~m}, 3 \mathrm{H}, \mathrm{C}_{\text {quino }}\right), 9.12-9.20\left(\mathrm{~m}, 2 \mathrm{H}, \mathrm{C}_{\text {quino }}\right)$.

${ }^{13} \mathrm{C}-\mathrm{NMR}\left(101 \mathrm{MHz}, \mathrm{D}_{2} \mathrm{O}\right): \delta 36.56\left(\mathrm{CH}_{2}\right), 42.69(\mathrm{SCH}), 58.84\left(\mathrm{NCH}_{2}\right), 121.86\left(\mathrm{C}_{\text {quino }}\right)$, 124.05 ( $\left.\mathrm{C}_{\text {quino }}\right), 127.31\left(\mathrm{C}_{\text {quino }}\right), 129.57\left(\mathrm{C}_{\text {quino }}\right), 130.95\left(\mathrm{C}_{\text {quino }}\right), 131.73\left(\mathrm{C}_{\text {quino }}\right), 133.43$ ( $\left.\mathrm{C}_{\text {quino }}\right), 149.40$ ( $\left.\mathrm{C}_{\text {quino }}\right), 149.60\left(\mathrm{C}_{\text {quino }}\right)$.

Anal. Calcd for $\mathrm{C}_{12} \mathrm{H}_{11} \mathrm{Cl}_{2} \mathrm{NS}$ : C 52.95, $\mathrm{H}$ 4.07, N 5.15, $\mathrm{Cl} 26.05, \mathrm{~S}$ 11.78. Found: C 53.13, H 4.17, N 5.39, Cl 26.46, S 12.21.

2-(Bromomethyl)-2H,3H-[1,4]thiazino[2,3,4-ij]quinolin-4-ium chloride (7). A solution of sulfuryl chloride $(0.082 \mathrm{~g}, 0.60 \mathrm{mmol})$ in chloroform $(10 \mathrm{~mL})$ was added dropwise to a solution of di(8-quinolinyl) disulfide $(0.194 \mathrm{~g}, 0.60 \mathrm{mmol})$ in chloroform $(10 \mathrm{~mL})$, and the mixture was stirred for $10 \mathrm{~min}$ at room temperature. A solution of allyl bromide $(0.147 \mathrm{~g}$, $1.2 \mathrm{mmol})$ in chloroform $(10 \mathrm{~mL})$ was added dropwise, and the reaction mixture stirred for $1 \mathrm{~h}$ at room temperature and $8 \mathrm{~h}$ at reflux temperature and $16 \mathrm{~h}$ at room temperature. The mixture was filtered and the solvent was removed by rotary evaporator. The residue was dried in a vacuum, producing the product $(0.342 \mathrm{~g}, 90 \%$ yield $)$ as a yellow powder, $\operatorname{mp} 162-164^{\circ} \mathrm{C}$.

${ }^{1} \mathrm{H}-\mathrm{NMR}\left(400 \mathrm{MHz}, \mathrm{D}_{2} \mathrm{O}\right): \delta 3.70-3.76\left(\mathrm{~m}, 1 \mathrm{H}, \mathrm{CH}_{2}\right), 4.04-4.09\left(\mathrm{~m}, 1 \mathrm{H}, \mathrm{CH}_{2}\right), 4.25$ (s, $1 \mathrm{H}, \mathrm{SCH}), 5.38\left(\mathrm{~d}, J=14.7 \mathrm{~Hz}, 1 \mathrm{H}, \mathrm{NCH}_{2}\right), 5.38\left(\mathrm{~d}, J=14.7 \mathrm{~Hz}, 1 \mathrm{H}, \mathrm{NCH}_{2}\right), 7.90-7.92(\mathrm{~m}$, $\left.1 \mathrm{H}, \mathrm{C}_{\text {quino }}\right), 8.09$ (s, 2H, $\left.\mathrm{C}_{\text {quino }}\right), 8.14-8.16\left(\mathrm{~m}, 1 \mathrm{H}, \mathrm{C}_{\text {quino }}\right), 9.16-9.18\left(\mathrm{~m}, 1 \mathrm{H}, \mathrm{C}_{\text {quino }}\right), 9.22(\mathrm{~s}$, $\left.1 \mathrm{H}, \mathrm{C}_{\text {quino }}\right)$.

${ }^{13} \mathrm{C}-\mathrm{NMR}\left(101 \mathrm{MHz}, \mathrm{D}_{2} \mathrm{O}\right): \delta 36.53\left(\mathrm{CH}_{2}\right), 42.65(\mathrm{SCH}), 58.81\left(\mathrm{NCH}_{2}\right), 121.83\left(\mathrm{C}_{\text {quino }}\right)$, 124.34 ( $\left.\mathrm{C}_{\text {quino }}\right), 127.24$ ( $\left.\mathrm{C}_{\text {quino }}\right), 129.51$ ( $\left.\mathrm{C}_{\text {quino }}\right), 130.89$ ( $\left.\mathrm{C}_{\text {quino }}\right), 132.62$ ( $\left.\mathrm{C}_{\text {quino }}\right), 133.35$ ( $\left.\mathrm{C}_{\text {quino }}\right), 149.34$ ( $\left.\mathrm{C}_{\text {quino }}\right), 149.58\left(\mathrm{C}_{\text {quino }}\right)$.

Anal. Calcd for $\mathrm{C}_{12} \mathrm{H}_{11}$ BrClNS: C 45.52, H 3.50, N 4.42, Br 25.23, Cl 11.20, S 10.13. Found: C 45.83, H 3.71, N 4.59, Br 25.64, Cl 11.56, S 10.69.

2-(Cyanomethyl)-2H,3H-[1,4]thiazino[2,3,4-ij]quinolin-4-ium chloride (8). A solution of sulfuryl chloride $(0.059 \mathrm{~g}, 0.44 \mathrm{mmol})$ in chloroform $(10 \mathrm{~mL})$ was added dropwise to a solution of di(8-quinolinyl) disulfide $(0.140 \mathrm{~g}, 0.44 \mathrm{mmol})$ in chloroform $(10 \mathrm{~mL})$, and the mixture was stirred for $10 \mathrm{~min}$ at room temperature. A solution of allyl cyanide $(0.059 \mathrm{~g}$, $0.88 \mathrm{mmol})$ in chloroform $(10 \mathrm{~mL})$ was added dropwise, and the reaction mixture stirred for $1 \mathrm{~h}$ at room temperature and $8 \mathrm{~h}$ at reflux temperature. After cooling in the refrigerator, the formed precipitate was filtered off and dried in a vacuum, producing the product $(0.223 \mathrm{~g}$, $96 \%$ yield) as a yellow powder, $\mathrm{mp} 183-185{ }^{\circ} \mathrm{C}$.

${ }^{1} \mathrm{H}-\mathrm{NMR}\left(400 \mathrm{MHz},\left(\mathrm{CD}_{3}\right)_{2} \mathrm{CO}\right): \delta 2.97\left(\mathrm{qd}, J=17.5,7.0 \mathrm{~Hz}, 1 \mathrm{H}, \mathrm{CH}_{2}\right), 4.18(\mathrm{dd}, J=12.8$, $6.7 \mathrm{~Hz}, 1 \mathrm{H}, \mathrm{SCH}), 5.11\left(\mathrm{dd}, J=14.3,6.7 \mathrm{~Hz}, 1 \mathrm{H}, \mathrm{NCH}_{2}\right), 5.48\left(\mathrm{~d}, J=14.3 \mathrm{~Hz}, 1 \mathrm{H}, \mathrm{NCH}_{2}\right.$ ), 7.71-7.75 (m, 1H, $\left.\mathrm{C}_{\text {quino }}\right), 7.88-8.00\left(\mathrm{~m}, 3 \mathrm{H}, \mathrm{C}_{\text {quino }}\right), 8.99-9.02\left(\mathrm{~m}, 2 \mathrm{H}, \mathrm{C}_{\text {quino }}\right)$.

${ }^{13} \mathrm{C}-\mathrm{NMR}\left(101 \mathrm{MHz},\left(\mathrm{CD}_{3}\right)_{2} \mathrm{CO}\right): \delta 20.65\left(\mathrm{CH}_{2}\right), 31.61(\mathrm{SCH}), 60.67\left(\mathrm{NCH}_{2}\right), 117.26$ $(\mathrm{CN}), 121.58$ ( $\left.\mathrm{C}_{\text {quino }}\right), 123.30\left(\mathrm{C}_{\text {quino }}\right), 125.36\left(\mathrm{C}_{\text {quino }}\right), 127.45\left(\mathrm{C}_{\text {quino }}\right), 129.43\left(\mathrm{C}_{\text {quino }}\right), 130.64$ ( $\left.\mathrm{C}_{\text {quino }}\right), 133.53$ ( $\left.\mathrm{C}_{\text {quino }}\right), 149.33\left(\mathrm{C}_{\text {quino }}\right), 149.45\left(\mathrm{C}_{\text {quino }}\right)$.

Anal. Calcd for $\mathrm{C}_{13} \mathrm{H}_{11} \mathrm{ClN}_{2} \mathrm{~S}$ : C 59.42, $\mathrm{H} 4.22, \mathrm{~N} 10.66, \mathrm{Cl} 13.49, \mathrm{~S}$ 12.20. Found: C 59.83, H 4.47, N 10.99, Cl 14.00, S 12.74.

\subsection{Synthesis of Compounds $\mathbf{9 - 1 3}$}

3-(1H-Imidazol-1-yl)-2H,3H-[1,4]thiazino[2,3,4-ij]quinolin-4-ium chloride (9). A solution of sulfuryl chloride $(0.081 \mathrm{~g}, 0.60 \mathrm{mmol})$ in methylene chloride $(10 \mathrm{~mL})$ was added dropwise to a solution of di(8-quinolinyl) disulfide $(0.192 \mathrm{~g}, 0.60 \mathrm{mmol})$ in methylene chloride $(10 \mathrm{~mL})$, and the mixture was stirred for $10 \mathrm{~min}$ at room temperature. A solution of 1-vinylimidazole $(0.113 \mathrm{~g}, 1.2 \mathrm{mmol})$ in methylene chloride $(10 \mathrm{~mL})$ was added dropwise, and the reaction mixture was stirred for $48 \mathrm{~h}$ at room temperature. The formed precipitate was filtered off, washed with cold hexane and dried in a vacuum, producing the product $(0.263 \mathrm{~g}$, $75 \%$ yield) as a dark yellow powder, $\mathrm{mp} 127-129^{\circ} \mathrm{C}$. 
${ }^{1} \mathrm{H}-\mathrm{NMR}\left(400 \mathrm{MHz}\right.$, methanol- $\left.d_{4}\right): \delta 3.69\left(\mathrm{dd}, J=14.2,3.9 \mathrm{~Hz}, 1 \mathrm{H}, \mathrm{SCH}_{2}\right), 3.82(\mathrm{dd}$, $\left.J=14.2,1.4 \mathrm{~Hz}, 1 \mathrm{H}, \mathrm{SCH}_{2}\right), 6.41(\mathrm{~s}, 1 \mathrm{H}, \mathrm{NCH}), 7.25(\mathrm{~s}, 2 \mathrm{H}, \mathrm{CH}=\mathrm{CH}), 7.87(\mathrm{t}, J=7.9 \mathrm{~Hz}, 1 \mathrm{H}$, $\mathrm{NCHN}), 8.06-8.18\left(\mathrm{~m}, 4 \mathrm{H}, \mathrm{C}_{\text {quino }}\right), 9.27-9.29\left(\mathrm{~m}, 1 \mathrm{H}, \mathrm{C}_{\text {quino }}\right), 9.51-9.52\left(\mathrm{~m}, 1 \mathrm{H}, \mathrm{C}_{\text {quino }}\right)$.

${ }^{13} \mathrm{C}-\mathrm{NMR}\left(101 \mathrm{MHz}\right.$, methanol- $\left.d_{4}\right): \delta 29.45\left(\mathrm{t}, J_{\mathrm{C}-\mathrm{H}} 145.7 \mathrm{~Hz}, \mathrm{SCH}_{2}\right), 94.35\left(\mathrm{~d}, J_{\mathrm{C}-\mathrm{H}}\right.$ 168.6 Hz, NCH), $121.41(\mathrm{CH}=\mathrm{CH}), 122.50\left(\mathrm{C}_{\text {quino }}\right), 128.31\left(\mathrm{C}_{\text {quino }}\right), 128.49\left(\mathrm{C}_{\text {quino }}\right), 130.65$ $\left(\mathrm{C}_{\text {quino }}\right), 133.19\left(\mathrm{C}_{\text {quino }}\right), 133.62\left(\mathrm{C}_{\text {quino }}\right), 134.00\left(\mathrm{C}_{\text {quino }}\right), 135.89\left(\mathrm{C}_{\text {quino }}\right), 150.05$ ( $\left.\mathrm{C}_{\text {quino }}\right)$, $152.11(\mathrm{~N}=\mathrm{CHN})$.

Anal. Calcd for $\mathrm{C}_{14} \mathrm{H}_{12} \mathrm{~N}_{3} \mathrm{ClS}$ : C 58.03, $\mathrm{H} 4.17, \mathrm{Cl} 12.23, \mathrm{~N} 14.50, \mathrm{~S} 11.07$. Found: C 55.94, H 4.52, Cl 12.69, N 5.23, S 11.51.

3-(2-Oxopyrrolidin-1-yl)-2H,3H-[1,4]thiazino[2,3,4-ij]quinolin-4-ium perchlorate (10). A solution of sulfuryl chloride $(0.107 \mathrm{~g}, 0.79 \mathrm{mmol})$ in methylene chloride $(10 \mathrm{~mL})$ was added dropwise to a solution of $\mathrm{di}(8$-quinolinyl $)$ disulfide $(0.254 \mathrm{~g}, 0.79 \mathrm{mmol})$ in methylene chloride $(10 \mathrm{~mL})$, and the mixture was stirred for $10 \mathrm{~min}$ at room temperature. Anhydrous $\mathrm{KClO}_{4}(0.219 \mathrm{~g}, 1.58 \mathrm{mmol})$ was added and the mixture was stirred for $10 \mathrm{~min}$. A solution of $N$-vinylpyrrolidone $(0.176 \mathrm{~g}, 1.58 \mathrm{mmol})$ in methylene chloride $(10 \mathrm{~mL})$ was added dropwise, and the reaction mixture was stirred for $24 \mathrm{~h}$ at room temperature. After filtration the solvent was removed by rotary evaporator. The residue was recrystallized from methanol/ether $1: 1$ and dried in a vacuum, producing the product $(0.41 \mathrm{~g}, 70 \%$ yield $)$ as a orange powder, $\mathrm{mp} 149-150{ }^{\circ} \mathrm{C}$.

${ }^{1} \mathrm{H}-\mathrm{NMR}\left(400 \mathrm{MHz}, \mathrm{D}_{2} \mathrm{O}\right): \delta 2.06-2.25\left(\mathrm{~m}, 2 \mathrm{H}, \mathrm{CH}_{2}\right), 2.61-2.67\left(\mathrm{~m}, 2 \mathrm{H}, \mathrm{CH}_{2}\right), 3.37-3.42$ $\left(\mathrm{m}, 1 \mathrm{H}, \mathrm{SCH}_{2}\right), 3.80-3.88\left(\mathrm{~m}, 2 \mathrm{H}, \mathrm{CH}_{2}\right), 3.97-4.00\left(\mathrm{~m}, 1 \mathrm{H}, \mathrm{SCH}_{2}\right), 7.19(\mathrm{~s}, 1 \mathrm{H}, \mathrm{NCH}), 7.92-$ $7.96\left(\mathrm{~m}, 1 \mathrm{H}, \mathrm{C}_{\text {quino }}\right), 8.10-8.15\left(\mathrm{~m}, 1 \mathrm{H}, \mathrm{C}_{\text {quino }}\right), 8.18-8.22\left(\mathrm{~m}, 1 \mathrm{H}, \mathrm{C}_{\text {quino }}\right), 9.21-9.25(\mathrm{~m}$, $\left.2 \mathrm{H}, \mathrm{C}_{\text {quino }}\right)$.

${ }^{13} \mathrm{C}-\mathrm{NMR}\left(101 \mathrm{MHz}, \mathrm{D}_{2} \mathrm{O}\right): \delta 18.24\left(\mathrm{CH}_{2}\right), 26.61\left(\mathrm{CH}_{2}\right), 30.73\left(\mathrm{CH}_{2}\right), 45.32\left(\mathrm{SCH}_{2}\right)$, $72.01(\mathrm{NCH}), 122.28\left(\mathrm{C}_{\text {quino }}\right), 125.66\left(\mathrm{C}_{\text {quino }}\right), 128.45\left(\mathrm{C}_{\text {quino }}\right), 129.91\left(\mathrm{C}_{\text {quino }}\right), 132.00\left(\mathrm{C}_{\text {quino }}\right)$, 134.39 ( $\left.\mathrm{C}_{\text {quino }}\right), 134.96\left(\mathrm{C}_{\text {quino }}\right), 147.10\left(\mathrm{C}_{\text {quino }}\right), 151.10\left(\mathrm{C}_{\text {quino }}\right), 180.49(\mathrm{C}=\mathrm{O})$.

Anal. Calcd for $\mathrm{C}_{15} \mathrm{H}_{15} \mathrm{~N}_{2} \mathrm{O}_{5} \mathrm{ClS}$ : C 48.59, $\mathrm{H} 4.08, \mathrm{~N} 7.55, \mathrm{Cl} 9.56, \mathrm{~S}$ 8.65. Found: $\mathrm{C}$ 48.69, H 4.21, N 7.75, Cl 9.70, S 8.91.

3-Ethoxy-2H,3H-[1,4]thiazino[2,3,4-ij]quinolin-4-ium chloride (11). A solution of sulfuryl chloride $(0.045 \mathrm{~g}, 0.33 \mathrm{mmol})$ in methylene chloride $(10 \mathrm{~mL})$ was added dropwise to a solution of di(8-quinolinyl) disulfide $(0.106 \mathrm{~g}, 0.48 \mathrm{mmol})$ in methylene chloride $(5 \mathrm{~mL})$, and the mixture was stirred for $10 \mathrm{~min}$ at room temperature. A solution of vinyl ethyl ether $(0.048 \mathrm{~g}, 0.66 \mathrm{mmol})$ in methylene chloride $(10 \mathrm{~mL})$ was added dropwise, and the reaction mixture stirred for $20 \mathrm{~h}$ at room temperature. The solvent was removed by rotary evaporator and the residue was dried in a vacuum, producing the product $(0.177 \mathrm{~g}$, $\sim 100 \%$ yield) as an orange oil.

${ }^{1} \mathrm{H}-\mathrm{NMR}\left(400 \mathrm{MHz}, \mathrm{D}_{2} \mathrm{O}\right): \delta 1.19\left(\mathrm{t}, J=7.0 \mathrm{~Hz}, 3 \mathrm{H}, \mathrm{CH}_{3}\right), 3.66-3.74\left(\mathrm{~m}, 2 \mathrm{H}, \mathrm{SCH}_{2}\right.$, $\left.\mathrm{OCH}_{2}\right), 3.81\left(\mathrm{dd}, J=14.3,1.9 \mathrm{~Hz}, 1 \mathrm{H}, \mathrm{SCH}_{2}\right), 4.00\left(\mathrm{dd}, J=9.2,7.0 \mathrm{~Hz}, 1 \mathrm{H}, \mathrm{OCH}_{2}\right), 6.52(\mathrm{~d}$, $J=1.9 \mathrm{~Hz}, 1 \mathrm{H}, \mathrm{NCH}), 7.81-7.85\left(\mathrm{~m}, 1 \mathrm{H}, \mathrm{C}_{\text {quino }}\right), 8.04-8.06\left(\mathrm{~m}, 1 \mathrm{H}, \mathrm{C}_{\text {quino }}\right), 8.10-8.15(\mathrm{~m}, 2 \mathrm{H}$, $\left.\mathrm{C}_{\text {quino }}\right), 9.21-9.24\left(\mathrm{~m}, 1 \mathrm{H}, \mathrm{C}_{\text {quino }}\right), 9.38-9.40\left(\mathrm{~m}, 1 \mathrm{H}, \mathrm{C}_{\text {quino }}\right)$.

${ }^{13} \mathrm{C}-\mathrm{NMR}\left(101 \mathrm{MHz}, \mathrm{D}_{2} \mathrm{O}\right): \delta 13.81\left(\mathrm{CH}_{3}\right), 28.51\left(\mathrm{SCH}_{2}\right), 66.27\left(\mathrm{OCH}_{2}\right), 91.48(\mathrm{NCH})$, $121.24\left(\mathrm{C}_{\text {quino }}\right), 125.52\left(\mathrm{C}_{\text {quino }}\right), 127.44\left(\mathrm{C}_{\text {quino }}\right), 128.09\left(\mathrm{C}_{\text {quino }}\right), 129.39\left(\mathrm{C}_{\text {quino }}\right), 131.55\left(\mathrm{C}_{\text {quino }}\right)$, 133.08 ( $\left.\mathrm{C}_{\text {quino }}\right), 148.21$ ( $\left.\mathrm{C}_{\text {quino }}\right), 151.05$ ( $\left.\mathrm{C}_{\text {quino }}\right)$.

Anal. Calcd for $\mathrm{C}_{13} \mathrm{H}_{14} \mathrm{NClOS}$ : C 58.31, H 5.27, N 5.23, $\mathrm{Cl} 13.24, \mathrm{~S} 11.97$. Found: C 58.60, H 5.36, N 5.54, Cl 13.61, S 12.42 .

3-Butoxy-2H,3H-[1,4]thiazino[2,3,4-ij]quinolin-4-ium chloride (12). A solution of sulfuryl chloride $(0.077 \mathrm{~g}, 0.57 \mathrm{mmol})$ in methylene chloride $(10 \mathrm{~mL})$ was added dropwise to a solution of di(8-quinolinyl) disulfide $(0.183 \mathrm{~g}, 0.57 \mathrm{mmol})$ in methylene chloride $(5 \mathrm{~mL})$, and the mixture was stirred for $10 \mathrm{~min}$ at room temperature. A solution of vinyl butyl ether $(0.114 \mathrm{~g}, 1.14 \mathrm{mmol})$ in methylene chloride $(10 \mathrm{~mL})$ was added dropwise, and the reaction mixture stirred for $24 \mathrm{~h}$ at room temperature. The solvent was removed by rotary evaporator and the residue was dried in a vacuum, producing the product $(0.338 \mathrm{~g}$, $\sim 100 \%$ yield) as a light yellow powder, mp $139-140{ }^{\circ} \mathrm{C}$. 
${ }^{1} \mathrm{H}-\mathrm{NMR}\left(400 \mathrm{MHz}, \mathrm{D}_{2} \mathrm{O}\right): \delta 0.72\left(\mathrm{t}, J=7.4 \mathrm{~Hz}, 3 \mathrm{H}, \mathrm{CH}_{3}\right), 1.16(\mathrm{dt}, J=15.5,7.5 \mathrm{~Hz}, 2 \mathrm{H}$, $\left.\mathrm{CH}_{2}\right), 1.50\left(\mathrm{~s}, 2 \mathrm{H}, \mathrm{CH}_{2}\right), 3.58\left(\mathrm{~d}, J=7.8 \mathrm{~Hz}, 1 \mathrm{H}, \mathrm{OCH}_{2}\right), 3.72\left(\mathrm{~d}, J=14.0 \mathrm{~Hz}, 1 \mathrm{H}, \mathrm{SCH}_{2}\right), 3.82$ $\left(\mathrm{d}, J=14.0 \mathrm{~Hz}, 1 \mathrm{H}, \mathrm{SCH}_{2}\right), 3.94\left(\mathrm{~d}, J=8.8 \mathrm{~Hz}, 1 \mathrm{H}, \mathrm{OCH}_{2}\right), 6.49(\mathrm{~s}, 1 \mathrm{H}, \mathrm{NCH}), 7.87-7.91(\mathrm{~m}$, $\left.1 \mathrm{H}, \mathrm{C}_{\text {quino }}\right), 8.07-8.16\left(\mathrm{~m}, 3 \mathrm{H}, \mathrm{C}_{\text {quino }}\right), 9.22-9.24\left(\mathrm{~m}, 1 \mathrm{H}, \mathrm{C}_{\text {quino }}\right), 9.34-9.36\left(\mathrm{~m}, 1 \mathrm{H}, \mathrm{C}_{\text {quino }}\right)$.

${ }^{13} \mathrm{C}-\mathrm{NMR}\left(101 \mathrm{MHz}, \mathrm{D}_{2} \mathrm{O}\right): \delta 12.64\left(\mathrm{CH}_{3}\right), 18.26\left(\mathrm{CH}_{2}\right), 28.44\left(\mathrm{CH}_{2}\right), 30.12\left(\mathrm{SCH}_{2}\right)$, $69.95\left(\mathrm{OCH}_{2}\right), 91.51(\mathrm{NCH}), 121.09\left(\mathrm{C}_{\text {quino }}\right), 124.41\left(\mathrm{C}_{\text {quino }}\right), 125.11\left(\mathrm{C}_{\text {quino }}\right), 127.42\left(\mathrm{C}_{\text {quino }}\right)$, 129.47 ( $\left.\mathrm{C}_{\text {quino }}\right), 131.64\left(\mathrm{C}_{\text {quino }}\right), 133.10\left(\mathrm{C}_{\text {quino }}\right), 148.08\left(\mathrm{C}_{\text {quino }}\right), 151.08\left(\mathrm{C}_{\text {quino }}\right)$.

Anal. Calcd for $\mathrm{C}_{15} \mathrm{H}_{18} \mathrm{NClOS}$ : C 60.90, H 6.13, N 4.73, $\mathrm{Cl} 11.98, \mathrm{~S} 10.84$. Found: C 61.20, H 6.36, N 5.04, Cl 12.29, S 11.10.

$7 a H, 8 H, 9 H, 10 a H$-Furo[2', 3':5,6][1,4] thiazino[2,3,4-ij]quinolin-11-ium perchlorate (13). A solution of sulfuryl chloride $(0.079 \mathrm{~g}, 0.58 \mathrm{mmol})$ in methylene chloride $(10 \mathrm{~mL})$ was added dropwise to a solution of $\mathrm{di}(8$-quinolinyl $)$ disulfide $(0.187 \mathrm{~g}, 0.58 \mathrm{mmol})$ in methylene chloride $(10 \mathrm{~mL})$, and the mixture was stirred for $10 \mathrm{~min}$ at room temperature. Anhydrous $\mathrm{KClO}_{4}(0.162 \mathrm{~g}, 1.17 \mathrm{mmol})$ was added and the mixture was stirred for $10 \mathrm{~min}$. A solution of 2,3-dihydrofuran $(0.082 \mathrm{~g}, 1.17 \mathrm{mmol})$ in methylene chloride $(10 \mathrm{~mL})$ was added dropwise, and the reaction mixture was stirred for $48 \mathrm{~h}$ at room temperature. After filtration the solvent was removed by rotary evaporator. The residue was recrystallized from methanol/ether $1: 1$ and dried in a vacuum, producing the product $(0.278 \mathrm{~g}, 72 \%$ yield $)$ as an orange powder, $\mathrm{mp} 219-220^{\circ} \mathrm{C}$.

${ }^{1} \mathrm{H}-\mathrm{NMR}\left(400 \mathrm{MHz}, \mathrm{DMSO}-d_{6}\right): \delta 1.81-1.92\left(\mathrm{~m}, 1 \mathrm{H}, \mathrm{CH}_{2}\right), 2.60-2.64\left(\mathrm{~m}, 1 \mathrm{H}, \mathrm{CH}_{2}\right)$, 4.10-4.15 (m, 1H, SCH), 4.22-4.33 (m, 2H, CH $\left.{ }_{2} \mathrm{O}\right), 6.52(\mathrm{~d}, J=4.7 \mathrm{~Hz}, 1 \mathrm{H}, \mathrm{NCH}), 7.82-7.86$ $\left(\mathrm{m}, 1 \mathrm{H}, \mathrm{C}_{\text {quino }}\right), 8.02-8.04\left(\mathrm{~m}, 1 \mathrm{H}, \mathrm{C}_{\text {quino }}\right), 8.15-8.20\left(\mathrm{~m}, 1 \mathrm{H}, \mathrm{C}_{\text {quino }}\right), 9.19-9.21(\mathrm{~m}, 1 \mathrm{H}$, $\left.\mathrm{C}_{\text {quino }}\right), 9.57-9.58\left(1 \mathrm{H}, \mathrm{C}_{\text {quino }}\right)$.

${ }^{13} \mathrm{C}-\mathrm{NMR}\left(101 \mathrm{MHz}, \mathrm{DMSO}-d_{6}\right): \delta 28.50\left(\mathrm{CH}_{2}\right), 37.36(\mathrm{SCH}), 68.90\left(\mathrm{CH}_{2} \mathrm{O}\right), 91.62$ $(\mathrm{NCH}), 121.84$ ( $\left.\mathrm{C}_{\text {quino }}\right), 122.15$ ( $\left.\mathrm{C}_{\text {quino }}\right), 127.44\left(\mathrm{C}_{\text {quino }}\right), 129.19\left(\mathrm{C}_{\text {quino }}\right), 130.24$ ( $\left.\mathrm{C}_{\text {quino }}\right)$, 132.91 ( $\left.\mathrm{C}_{\text {quino }}\right), 133.40\left(\mathrm{C}_{\text {quino }}\right), 146.62\left(\mathrm{C}_{\text {quino }}\right), 149.24\left(\mathrm{C}_{\text {quino }}\right)$.

Anal. Calcd for $\mathrm{C}_{13} \mathrm{H}_{12} \mathrm{NClO}_{5} \mathrm{~S}$ : C 47.35, $\mathrm{H}$ 3.67, $\mathrm{N} 4.25, \mathrm{Cl} 10.75, \mathrm{~S} 9.72$. Found: C 47.82, H 3.52, N 4.75, Cl 11.25, S 10.08.

\section{Conclusions}

Unsaturated heteroatom (4-pentenoic and 5-hexenoic acids, allyl chloride and bromide, allyl cyanate, ethyl vinyl and butyl vinyl ethers) and heterocyclic ( $N$-vinyl pyrrolidin2-one, 1-vinylimidazole and 2,3-dihydrofuran) compounds were used for the efficient regioselective synthesis of a novel family of [1,4]thiazino[2,3,4-ij]quinolin-4-ium derivatives by annulation reactions with 8-quinolinesulfenyl chloride.

The reactions with 4-pentenoic and 5-hexenoic acids, allylchloride, allylbromide and allyl cyanate included the electrophilic addition of the sulfur atom of sulfenyl chloride to the $\alpha$-carbon atom of the vinyl group ("anti-Markovnikov direction"), while the annulation reactions with $N$-vinyl pyrrolidin-2-one, 1-vinylimidazole, 2,3-dihydrofuran, ethyl vinyl and butyl vinyl ethers proceeded with the attachment of the sulfur atom to the $\beta$-carbon atom of the vinyl group ("Markovnikov direction"). We presume that in the latter case the reactions proceed via linear intermediates (Scheme 7) which are stabilized by the nitrogen or oxygen atom. In the case of the anti-Markovnikov direction of the reactions, there are no heteroatoms adjacent to the double bond which could stabilize the intermediates, and the reactions take place via thiiranium intermediates.

The antibacterial activity of novel water-soluble compounds against $E$. durans, B. subtilis and $E$. coli was evaluated and the compounds with high antibacterial activity have been found (Table 1). Compound 5, with its longer carbon chain, exhibited considerably higher activity against gram-positive E. durans and B. subtilis and was superior to antibiotic gentamicin in this respect. Bromo-containing compound 7 was 40 times more effective than its chlorine analogue 6 against E. durans. A comparison of compounds 11-13 revealed that products 11 and 13 (obtained from ethyl vinyl ether and 2,3-dihydrofuran) displayed superior activity compared to gentamicin against gram-positive bacteria. The highest activity 
was shown by product 10 (obtained from $N$-vinyl pyrrolidin-2-one), which significantly exceeded the activity of gentamicin and all obtained compounds against gram-positive bacteria and was more than a hundred times superior to this antibiotic against $B$. subtilis.

Supplementary Materials: The following are available online. Examples of NMR spectra of the obtained compounds.

Author Contributions: Conceptualization and the paper preparation, V.A.P.; methodology and research experiments, R.S.I.; antibacterial activity evaluation, L.A.B.; the data curation and supervision, S.V.A. All authors have read and agreed to the published version of the manuscript.

Funding: This research received no external funding.

Institutional Review Board Statement: Not applicable.

Informed Consent Statement: Not applicable.

Data Availability Statement: Not applicable.

Acknowledgments: The authors thank Baikal Analytical Center SB RAS for providing the instrumental equipment for structural investigations.

Conflicts of Interest: The authors declare no conflict of interest.

\section{References}

1. Andersson, M.I.; MacGowan, A.P. Development of the quinolones. J. Antimicrob. Chemother. 2003, 51, 1-11. [CrossRef] [PubMed]

2. Kumar, S.; Bawa, S.; Gupta, H. Biological activities of quinoline derivatives. Mini Rev. Med. Chem. 2009, 9, 1648-1654. [CrossRef] [PubMed]

3. Raut, K.; Thombare, R.; Zagade, P.; Kumbhar, N. Different biological activities of quinoline. World J. Pharm. Res. 2020, 9, 674-689.

4. Chung, P.-Y.; Bian, Z.-X.; Pun, H.-Y.; Chan, D.; Chan, A.S.-C.; Chui, C.-H.; Tang, J.C.-O.; Lam, K.-H. Recent advances in research of natural and synthetic bioactive quinolines. Future Med. Chem. 2015, 7, 947-967. [CrossRef]

5. Weyesa, A.; Mulugeta, E. Recent advances in the synthesis of biologically and pharmaceutically active quinoline and its analogues: A review. RSC Adv. 2020, 10, 20784-20793. [CrossRef]

6. Abass, M.; Alzandi, A.R.A.; Hassan, M.M.; Mohamed, N. Recent Advances on Diversity Oriented Heterocycle Synthesis of Fused Quinolines and Its Biological Evaluation. Polycycl. Arom. Comp. 2021, 1710856. [CrossRef]

7. Shiro, T.; Fukaya, T.; Tobe, M. The chemistry and biological activity of heterocycle-fused quinolinone derivatives: A review. Eur. J. Med. Chem. 2015, 97, 397-408. [CrossRef] [PubMed]

8. Feng, M.; Tang, B.; Liang, S.H.; Jiang, X. Sulfur Containing Scaffolds in Drugs: Synthesis and Application in Medicinal Chemistry. Curr. Top. Med. Chem. 2016, 16, 1200-1216. [CrossRef]

9. Good, J.A.D.; Kulen, A.M.; Almqvist, K.F.; Cairns, A.G.; Ponten, J.F. 2,3-Dihydrothiazolo[3,2-a]pyridin-5-one Derivatives, Intermediates Thereof, and Their Use as Antibacerial Agents. U.S. Patent 10,294,244, 21 May 2019.

10. Shi, F.; Li, C.; Xia, M.; Miao, K.; Zhao, Y.; Tu, S.; Zheng, W.; Zhang, G.; Ma, N. Green chemoselective synthesis of thiazolo[3,2a]pyridine derivatives and evaluation of their antioxidant and cytotoxic activities. Bioorg. Med. Chem. Lett. 2009, 19, 5565-5568. [CrossRef]

11. Manfroni, G.; Meschini, F.; Barreca, M.L.; Leyssen, P.; Samuele, A.; Iraci, N.; Sabatini, S.; Massari, S.; Maga, G.; Neyts, J.; et al. Pyridobenzothiazole derivatives as new chemotype targeting the HCV NS5B polymerase. Bioorg. Med. Chem. 2012, 20, 866-876. [CrossRef] [PubMed]

12. Li, S.; Huang, Q.; Liu, Y.J.; Zhang, X.L.; Liu, S.; He, C.; Gong, P. Design, synthesis and antitumor activity of bisquinoline derivatives connected by 4-oxy-3-fluoroaniline moiety. Eur. J. Med. Chem. 2013, 64, 62-73. [CrossRef]

13. Panda, S.S.; Liaqat, S.; Girgis, A.S.; Samir, A.; Hall, C.D.; Katritzky, A.R. Novel antibacterial active quinolone-fluoroquinolone conjugates and 2D-QSAR studies. Bioorg. Med. Chem. Lett. 2015, 25, 3816-3821. [CrossRef] [PubMed]

14. Gao, C.; Fan, Y.L.; Zhao, F.; Ren, Q.C.; Wu, X.; Chang, L.; Gao, F. Quinolone derivatives and their activities against methicillinresistant Staphylococcus aureus (MRSA). Eur. J. Med. Chem. 2018, 157, 1081-1095. [CrossRef] [PubMed]

15. Hu, G.; Liang, J.; Liu, J.; Zhang, H. Preparation of propenone derivative of N-demethylated Rufloxacin as antitumor drugs. Chem. Abstr. 2020, 173, 407358.

16. Cen, S.; Yang, L.; Li, X.; Hu, G. Preparation method of Rufloxacin-containing bis-fluoroquinolone oxadiazole urea derivative applied to antitumor drug. Chem. Abstr. 2019, 171, 203187.

17. Fukuda, Y.; Seto, S.; Tanioka, A.; Ikeda, M. Preparation of pyridobenzothiazine derivatives having tachykinin antagonism, in particular, substance P receptor antagonism. Chem. Abstr. 2000, 132, 151827.

18. Hou, L.; Du, L.; Li, Y.; Hu, G.; Sun, J.; Zhang, C.; Shen, R.; Wang, N. Preparation of fluoroquinolone 1,3,4-thiadiazole urea rufloxacin derivatives useful for the treatment of cancer. Chem. Abstr. 2019, 171, 467857. 
19. Lapointe, G.; Mergo, W.; Moser, H.E.; Rivkin, A.; Skepper, C.K.; Williams, S.L. Preparation of tricyclic 2-quinolinones as antibacterials. Chem. Abstr. 2018, 169, 515481.

20. Hu, G.; Wang, G.; Jing, Y. 3-[[2-(4-Pyridinylcarbonyl)hydrazinylidene]methyl]-7-fluoroquinolone derivatives useful in the treatment of tuberculosis. Chem. Abstr. 2012, 158, 131756.

21. Musalov, M.V.; Yakimov, V.A.; Potapov, V.A.; Amosova, S.V.; Borodina, T.N.; Zinchenko, S.V. A novel methodology for the synthesis of condensed selenium heterocycles based on the annulation and annulation-methoxylation reactions of selenium dihalides. New J. Chem. 2019, 43, 18476-18483. [CrossRef]

22. Musalov, M.V.; Potapov, V.A. Selenium dihalides: New possibilities for the synthesis of selenium-containing heterocycles. Chem. Heterocycl. Compd. 2017, 53, 150-152. [CrossRef]

23. Accurso, A.A.; Cho, S.-H.; Amin, A.; Potapov, V.A.; Amosova, S.V.; Finn, M.G. Thia-, Aza-, and Selena[3.3.1]bicyclononane Dichlorides: Rates vs Internal Nucleophile in Anchimeric Assistance. J. Org. Chem. 2011, 76, 4392-4395. [CrossRef]

24. Potapov, V.A.; Amosova, S.V.; Abramova, E.V.; Lyssenko, K.A.; Musalov, M.V.; Finn, M.G. Transannular Addition of Selenium Dichloride and Dibromide to 1,5-Cyclooctadiene: Synthesis of 2,6-Dihalo-9-selenabicyclo[3.3.1]nonanes and Their Complexes with Selenium Dihalides. New J. Chem. 2015, 39, 8055-8059. [CrossRef]

25. Potapov, V.A.; Amosova, S.V.; Kashik, A.S. Reactions of selenium and tellurium metals with phenylacetylene in 3-phase catalytical systems. Tetrahedron Lett. 1989, 30, 613-616. [CrossRef]

26. Potapov, V.A.; Volkova, K.A.; Penzik, M.V.; Albanov, A.I.; Amosova, S.V. Reaction of selenium dichloride with divinyl selenide. Russ. J. Org. Chem. 2008, 44, 1556-1557. [CrossRef]

27. Potapov, V.A.; Malinovich, D.A.; Amosova, S.V.; Rusakov, Y.Y.; Bhasin, K.K. Reaction of 2-pyridylselenenyl bromide with divinyl selenide. Chem. Heterocycl. Comp. 2012, 48, 1129-1131. [CrossRef]

28. Potapov, V.A.; Musalova, M.V.; Ishigeev, R.S.; Musalov, M.V.; Panov, V.A.; Khabibulina, A.G.; Amosova, S.V.; Bhasin, K.K. Efficient and selective syntheses of novel unsaturated chalcogen-containing pyridine derivatives. Tetrahedron Lett. 2016, 57, 5341-5343. [CrossRef]

29. Potapov, V.A.; Ishigeev, R.S.; Amosova, S.V.; Borodina, T.N. Synthesis of a novel family of water-soluble 2H,3H-[1,3]thia- and -selenazolo[3,2-a]pyridin-4-ium heterocycles by annulation reactions. Tetrahedron Lett. 2019, 60, 475-479. [CrossRef]

30. Potapov, V.A.; Ishigeev, R.S.; Amosova, S.V. Synthesis of 3-(2-oxopyrrolidin-1-yl)-2H,3H-[1,3]selenazolo[3,2-a]pyridin-4-ium chloride. Russ. J. Org. Chem. 2017, 53, 1604-1605. [CrossRef]

31. Potapov, V.A.; Ishigeev, R.S.; Amosova, S.V. Regioselective Reaction of Pyridine-2-Sulfenyl Chloride with Isoeugenole. Russ. J. Org. Chem. 2018, 54, 1262-1263.

32. Potapov, V.A.; Ishigeev, R.S.; Shkurchenko, I.V.; Zinchenko, S.V. Amosova, S.V. Natural compounds and their structural analogs in regio- and stereoselective synthesis of new families of water-soluble $2 \mathrm{H}, 3 \mathrm{H}$-[1,3]thia- and -selenazolo[3,2-a]pyridin-4-ium heterocycles by annulation reactions. Molecules 2020, 25, 376. [CrossRef] [PubMed]

33. Potapov, V.A.; Ishigeev, R.S.; Amosova, S.V. Efficient Regioselective Synthesis of Novel Water-Soluble 2H,3H-[1,4]thiazino[2,3,4ij]quinolin-4-ium Derivatives by Annulation Reactions of 8-quinolinesulfenyl Halides. Molecules 2021, 26, 1116. [CrossRef] [PubMed]

34. Ishigeev, R.S.; Potapov, V.A.; Skurchenko, I.V.; Khabibulina, A.G.; Amosova, S.V. Synthesis of new polycyclic compounds via the reaction of quinoline-8-sulfenyl halides with cyclic alkenes. Chem. Heterocycl. Comp. 2021, 57, 314-319. [CrossRef]

35. Kim, D.G.; Vershinina, E.A.; Sharutin, V.V. Synthesis, transformations and halocyclization of 8-(prop-2-ynylsulfanyl)quinoline and 8-(2-bromoprop-2-enylsulfanyl)quinoline. J. Sulfur Chem. 2020, 41, 71-81. [CrossRef]

36. Kim, D.G. Halocyclization of 8-allylthioquinoline. Chem. Heterocycl. Compd. 1997, 33, 989-991. [CrossRef]

37. Batalov, V.I.; Kim, D.G.; Slepukhin, P.A. Heterocyclization of 8-(2-methyl-prop-2-enylsulfanyl)quinoline using electrophilic reagents. Chem. Heterocycl. Compd. 2013, 49, 1092-1096. [CrossRef]

38. Borisov, A.V.; Osmanov, V.K.; Borisova, G.N.; Matsulevich, Z.V.; Fukin, G.K. Synthesis of condensed sulfur- and nitrogencontaining heterocycles via polar cycloaddition of hetarene sulfenyl chlorides to a C-C multiple bond. Mendeleev Commun. 2009, 19, 49-51. [CrossRef]

39. Borisov, A.V.; Belsky, V.K.; Goncharova, T.V.; Borisova, G.N.; Osmanov, V.K.; Matsulevich, Z.V.; Frolova, N.G.; Savin, E.D. Sulfenyl halides in the synthesis of heterocycles. Part 2. Cyclization in reactions of hetarenesulfenyl chlorides with 3,3-dimethyl-1-butene. Chem. Heterocycl. Compd. 2005, 41, 771-777. [CrossRef]

40. Borisov, A.V.; Goncharova, T.V.; Borisova, G.N.; Osmanov, V.K.; Matsulevich, Z.V. Polar cycloaddition of 8-quinolinesulfenyl chloride to styrene. Chem. Heterocycl. Compd. 2001, 37, 382-383. [CrossRef]

41. Borisov, A.V.; Matsulevich, Z.V.; Osmanov, V.K.; Borisova, G.N.; Fukin, G.K.; Baranov, E.V. Unusual reaction of di(8-quinolyl) disulfide with norbornene. Chem. Heterocycl. Compd. 2010, 46, 1151-1153. [CrossRef]

42. Olah, G.A. 100 Years of Carbocations and Their Significance in Chemistry. J. Org. Chem. 2001, 66, 5943-5957. [CrossRef] [PubMed]

43. Koval', I.V. Sulfenyl chlorides in organic synthesis. Russ. Chem. Rev. 1995, 64, 731-751. [CrossRef]

44. Rasteikiene, L.; Greiciute, D.; Lin'kova, M.G.; Knunyants, I.L. The Addition of Sulphenyl Chlorides to Unsaturated Compounds. Russ. Chem. Rev. 1977, 46, 548-564. [CrossRef]

45. Smit, V.A.; Zefirov, N.S.; Bodrikov, I.V.; Krimer, M.Z. Episulfonium ions: Myth and reality. Acc. Chem. Res. 1979, 12, 282-288. [CrossRef] 
46. Abu-yousef, I.A.; Harpp, D.N. New Sulfenyl Chloride Chemistry: Synthesis, Reactions and Mechanisms Toward Carbon-Carbon Double Bonds. Sulfur Rep. 2003, 24, 255-282. [CrossRef]

47. Denmark, S.E.; Vogler, T. Synthesis and Reactivity of Enantiomerically Enriched Thiiranium Ions. Chem. Eur. J. 2009, 15, 11737-11745. [CrossRef]

48. Denmark, S.E.; Collins, W.R.; Cullen, M.D. Observation of Direct Sulfenium and Selenenium Group Transfer from Thiiranium and Seleniranium Ions to Alkenes. J. Am. Chem. Soc. 2009, 131, 3490-3492. [CrossRef]

49. Kharasch, N.; Potempa, S.J.; Wehrmeister, H.L. The sulfenic acids and their derivatives. Chem. Rev. 1946, 39, 269-332. [CrossRef] [PubMed]

50. Koval', I.V. S-Cationoid reagents in organic synthesis. Russ. Chem. Rev. 1995, 64, 141-166. [CrossRef]

51. Mueller, W.H.; Butler, P.E. Orientational effects in the addition of acetylthiosulfenyl chloride to olefins. J. Org. Chem. 1967, 32, 2925-2929. [CrossRef]

52. Mueller, W.H.; Butler, P.E. Reaction of sulfenyl chlorides with allene. J. Org. Chem. 1968, 33, 1533-1537. [CrossRef]

53. Naredla, R.R.; Klumpp, D.A. Contemporary Carbocation Chemistry: Applications in Organic Synthesis. Chem. Rev. 2013, 113, 6905-6948. [CrossRef] [PubMed]

54. Wiegand, I.; Hilpert, K.; Hancock, R.E.W. Agar and broth dilution methods to determine the minimal inhibitory concentration (MIC) of antimicrobial substances. Nat. Protoc. 2008, 3, 163-175. [CrossRef] [PubMed] 